\title{
CETRIMIDE-NALIDIXIC ACID AGAR AS A SELECTIVE MEDIUM FOR PSEUDOMONAS AERUGINOSA
}

\author{
H. A. Lilly AND E. J. L. Lowbury \\ M.R.C. Industrial Injuries and Burns Unit, Birmingham Accident Hospital
}

THE selective medium for Pseudomonas aeruginosa, containing 0.03 per cent. cetrimide in Lemco agar base (Lowbury and Collins, 1955), was later modified by Brown and Lowbury (1965) to give more strongly fluorescent growth by the use of King's medium B (King, Ward and Raney, 1954) as the base. Both media have been found useful in the bacteriological examination of burns, urine, sputum and other pathological sources. Although cetrimide agar is strongly selective for Ps. aeruginosa, some strains of Gram-negative bacilli (especially Klebsiella spp. and Providencia) can grow on it. To suppress the growth of these organisms, Tinne et al. (1967) added $5 \mu \mathrm{g}$ per ml nalidixic acid to an agar medium containing 0.03 per cent. cetrimide. Goto and Enomoto (1970) obtained better results with a medium containing 0.02 per cent. cetrimide and $15 \mu \mathrm{g}$ per ml nalidixic acid.

We report here a comparison of 0.03 per cent. cetrimide agar (Brown and Lowbury) with a medium containing 0.02 per cent. cetrimide and $15 \mu \mathrm{g}$ per $\mathrm{ml}$ nalidixic acid in the same agar base for the isolation of Ps. aeruginosa from burns.

\section{MATERIALS AND METHODS}

Cetrimide agar. The medium containing 0.03 per cent. cetrimide was prepared in the manner described by Brown and Lowbury. The basal medium consisted of Proteose peptone no. 3 (Difco), $20 \mathrm{~g}$; New Zealand agar, $15 \mathrm{~g}$; glycerol, $10 \mathrm{~g}$; distilled water, $1000 \mathrm{ml}$. It was adjusted to $p \mathrm{H} 7.2$ and autoclaved for $15 \mathrm{~min}$. at $121^{\circ} \mathrm{C}$. The following ingredients were added to $100 \mathrm{ml}$ of the melted base: $1 \mathrm{ml}$. of a 15 per cent solution of $\mathrm{K}_{2} \mathrm{HPO}_{4}$ (anhydrous) and $1 \mathrm{ml}$ of a 15 per cent. solution of $\mathrm{MgSO}_{4}, 7 \mathrm{H}_{2} \mathrm{O}$; these solutions were prepared with distilled water and Seitz-filtered. A 2 per cent. Seitz-filtered solution of cetrimide (B.P.) was added to the basal medium to give a final concentration of 0.03 per cent.

Cetrimide-nalidixic acid agar. For the study on burns, the concentrations of cetrimide ( 0.02 per cent.) and nalidixic acid ( $15 \mu \mathrm{g}$ per $\mathrm{ml})$ used by Goto and Enomoto were used. Preliminary examination of a range of combinations of cetrimide and nalidixic acid in agar, with tests for viable counts of small inocula, led us independently to select these concentrations for the optimal growth of Ps. aeruginosa (six strains tested) and for the suppression of strains of other Gram-negative bacilli that had grown on cetrimide agar (Klebsiella spp., Escherichia coli, Proteus mirabilis and Bact. anitratum).

Comparison of cetrimide agar with cetrimide-nalidixic acid agar. A series of 5358 consecutive swabs from burns in this Unit were inoculated in parallel on cetrimide agar (CA) and on cetrimide-nalidixic acid agar (CNA). In the routine examination of burns our practice was to inoculate swabs moistened with nutrient broth in sequence on horse blood agar (containing 4 per cent. New Zealand agar), cetrimide agar and cooked meat broth. To allow equal proportions of CA and CNA plates to receive the first inoculation after blood agar, the order of inoculating them was reversed with successive swabs. The selective media were inoculated in marked areas without spreading the inoculum. All the plates were examined after 18 hours' incubation at $37^{\circ} \mathrm{C}$ by daylight and under ultraviolet irradiation for the detection of the yellow-green or blue-green fluorescent growth characteristic of Ps.aeruginosa (Lowbury, Lilly and Wilkins, 1962). Cooked meat broth cultures were subcultured, after incubation at $37^{\circ} \mathrm{C}$ for $24 \mathrm{hr}$, to plates of blood agar (with 4 per cent. agar) and by spot

Received 10 June 1971; accepted 6 July 1971.

J. MED. MICROBIOL.—VOL. 5 (1972) 
inoculation to CA and CNA; the subcultures were examined by daylight and by ultraviolet irradiation.

Characteristic growth showing typical fluorescence under UV irradiation on blood agar or on the selective media was described as presumptive Ps. aeruginosa; 143 of these strains, including isolates from each medium, were subjected to the following confirmatory tests: (1) oxidase reaction (Kovács, 1956); (2) oxidative metabolism of glucose (Hugh and Leifson, 1953); (3) pyocyanin production on Wahba and Darrell's medium (1965); (4) nitrate reduction to gas by the Griess-Ilosvay method (Wilson and Miles, 1964); and (5) growth at $42^{\circ} \mathrm{C}$ in nutrient broth. All the strains of presumptive Ps. aeruginosa tested were consistent with the description of this species.

\section{RESULTS}

The table shows the number of swabs from which bacterial growth occurred and the number from which presumptive Ps. aeruginosa were isolated on the two selective media, both by direct inoculation and by subculture from cooked meat broth cultures.

TABLE

Comparison of cetrimide agar and cetrimide-nalidixic acid agar for isolation of Ps. aeruginosa from a total of 5358 swabs from burns

\begin{tabular}{c|c|c|c|c}
\hline \multirow{2}{*}{ Medium } & \multicolumn{3}{|c}{ Number of swabs from burns that yielded } \\
\cline { 2 - 4 } & on direct inoculation & \multicolumn{2}{|c}{ on subculture from cooked meat broth } \\
\cline { 2 - 4 } & bacterial growth & $\begin{array}{c}\text { presumptive } \\
\text { Ps. aeruginosa }\end{array}$ & bacterial growth & $\begin{array}{c}\text { presumptive } \\
\text { Ps. aeruginosa }\end{array}$ \\
\hline Cetrimide agar & 535 & $\begin{array}{c}285 \\
(5.3 \text { per cent. })\end{array}$ & 1290 & $\begin{array}{c}477 \\
(8.9 \text { per cent. })\end{array}$ \\
\hline $\begin{array}{c}\text { Cetrimide- } \\
\text { nalidixic acid } \\
\text { agar }\end{array}$ & 335 & $\begin{array}{c}329 \\
(6.1 \text { per cent. })\end{array}$ & $\begin{array}{c}513 \\
(9.6 \text { per cent. })\end{array}$ \\
\hline
\end{tabular}

On direct inoculation, CNA gave an appreciably greater yield (6.1 per cent.) of presumptive $P$ s. aeruginosa than CA (5.3 per cent.), but the proportion of plates showing bacterial growth was much higher for CA than for CNA. On subculture from cooked meat broth the difference in selectiveness of the media was even more pronounced, but the difference in the proportions of swabs yielding presumptive Ps. aeruginosa on the two media was smaller than on direct inoculation. Direct inoculation of blood agar, which preceded inoculation of the selective media, gave a higher yield of presumptive Ps. aeruginosa (295) than inoculation on CA (285), but a lower yield than CNA (329).

These results show CNA to be a more satisfactory selective medium for Ps. aeruginosa than CA. This is due both to better suppression of other Gram-negative bacilli on CNA, and to a smaller degree of inhibition of Ps. aeruginosa by CNA than by CA. A relatively small number of bacteria, other than Ps. aeruginosa, grew on CNA, either from direct inoculation of swabs or on subculture from liquid medium. Cetrimide agar, with 0.03 per cent. cetrimide, appeared to have stronger inhibitory action against small inocula of some strains of $P s$. aeruginosa than had been found in earlier studies, and the reduction of its concentration to 0.02 per cent. was probably an important factor in the improved quality of the new medium. 


\section{SUMMARY}

A series of 5358 consecutive swabs from burns were inoculated in duplicate on 0.03 per cent. cetrimide agar and on an agar medium containing 0.02 per cent. cetrimide with $15 \mu \mathrm{g}$ per $\mathrm{ml}$ nalidixic acid. A larger number of swabs yielded Ps. aeruginosa and a smaller number yielded growth of other bacteria on cetrimide-nalidixic acid than on cetrimide agar.

\section{REFERENCES}

BROWN, V. I., AND LowBURY, E. J. L. 1965. Use of an improved cetrimide agar medium and other cultural methods for Pseudomonas aeruginosa. J. Clin. Path., 18, 752.

Goto, S., AND ENomoto, S. 1970. Nalidixic acid cetrimide agar: a new selective plating medium for the selective isolation of Pseudomonas aeruginosa. Jap. J. Microbiol., 14, 65.

HUGH, R., AND LEIFSON, E. 1953. The taxonomic significance of fermentative versus oxidative metabolism of carbohydrates by various Gram-negative bacteria. J. Bact., 66, 24.

KING, E. O., WARD, M. K., AND RANEY, D. E. 1954. Two simple media for the demonstration of pyocyanin and fluorescin. J. Lab. Clin. Med., 44, 301.

Kovács, N. 1956. Identification of Pseudomonas pyocyanea by the oxidase reaction. Nature, Lond., 178, 703.

LowBURY, E. J. L., AND Collins, A. 1955. Use of a new cetrimide product in selective medium for Pseudomonas pyocyanea. J. Clin. Path., 8, 47.

LowbURY, E. J. L., LiLly, H. A., AND Wilkins, M. D. 1962. A cabinet for the detection of fluorescent bacterial cultures. J. Clin. Path., 15, 339.

Tinne, J. E., Gordon, A. M., Bain, W. H., AND MACKEY, W. A. 1967. Cross-infection by Pseudomonas aeruginosa as a hazard of intensive surgery. Br. Med. J., 4, 313.

WaHba, A. H., AND Darrell, J. H. 1965. The identification of atypical strains of Pseudomonas aeruginosa. J. Gen. Microbiol., 38, 329.

Wirson, G. S., AND Miles, A. A. 1964. Topley and Wilson's Principles of bacteriology and immunity, 5th ed., London, p. 491. 